\title{
The choice of a diet quality indicator to evaluate the nutritional health of populations
}

\author{
Lise Dubois ${ }^{1}{ }^{*}$, Manon Girard ${ }^{1}$ and Nathalie Bergeron ${ }^{2}$ \\ 'Département de Médecine Sociale et Préventive, Pavillon de l'Est, Université Laval, Sainte-Foy, Québec, \\ Canada G1K 7P4: ${ }^{2}$ Département des Sciences des Aliments et de Nutrition, Pavillon Paul-Comtois, Université \\ Laval, Sainte-Foy, Québec, Canada G1K 7P4
}

\begin{abstract}
Background: The USA and Canada both want to reduce social health inequalities in their population. These two countries have recently begun a process of harmonization of their nutrient recommendations.

Objective: To develop a standardized indicator to measure the impact of these recommendations on the health of different social groups in North America. The authors have compared three of the methods currently used for measuring overall diet quality for a population.

Design and setting: The three methods, adjusted to the 1990 Canadian nutrition recommendations, were used to analyse the Québec Nutrition Survey data collected by Santé Québec in 1990.

Results: The authors found that the indicator developed by Kennedy and collaborators works best for analysing the Québec data. Moreover, it allows comparisons with the USA. Some questions, such as whether or not to add calories from alcohol consumption to the model and whether the indicators should be adjusted to the different cultures and specific population groups remain unanswered.

Conclusions: In order to determine the role of nutrition in social health inequalities, it is important to develop standard indicators that are suitable for monitoring the relationship between dietary recommendations and eating habits.
\end{abstract}

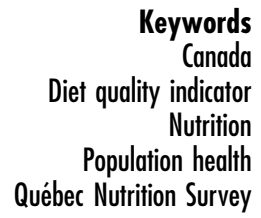

The USA and Canada have common concerns about the health of their populations. They both want to reduce the incidence of chronic diseases, improve quality of life and reduce social health inequalities ${ }^{1,2}$. In this regard, nutrition is recognized as an important determinant of population health. Indeed, the regression of the incidence of infectious diseases during the 20th century was partly due to a better access to high quality foods for most of the population ${ }^{3}$. This abundance has, however, contributed to the development of chronic diseases, such as cancer and coronary heart disease, which have become the leading causes of death in developed countries.

\section{Dietary recommendations in Canada and the USA}

Since the beginning of the 20th century, research in nutrition has determined the body needs and the content of foods for various nutrients. This information had been regularly updated and conveyed to the population. However, it was not until the 1970s that concerns about chronic diseases (mainly cardiovascular disease and certain types of cancer) started to be taken into account in dietary recommendations, both in the USA and Canada ${ }^{4,5}$. Today, the population can refer to the recommended dietary allowances (RDA) in the $\mathrm{USA}^{6}$ and to the recommended dietary intakes (RDI) in Canada 5 . These recommendations apply to healthy people and the minimum allowances of all nutrients exceed individual needs to take into account group variability ${ }^{7}$. The primary objective of dietary advice is to prevent chronic diseases, even though our daily food intake is still dictated by the necessity to meet body needs for energy and nutrients ${ }^{5}$. These two main objectives of dietary recommendations - the control of chronic diseases and of nutrient deficiencies - are communicated to the population by the dietary guidelines, illustrated in the American Pyramid Food Guide and in the Canadian Rainbow Food Guide.

The USA and Canada have recently begun to harmonize their nutrient recommendations, but this process is still in progress. In the future, American and Canadian citizens will both refer to the dietary reference intakes (DRI) which will also include certain nonnutrient food elements, such as fibre or carotenoids, which are also related to the prevention of chronic diseases ${ }^{6}$ 


\section{Global measurement of the impact of recommendations}

The harmonization of the American and Canadian recommendations is a good opportunity to attempt to standardize an indicator that could measure the compliance of the population to those recommendations. Similarly, the development of a standardized indicator to assess diet quality in relation to dietary recommendations will help us to determine the role of nutrition in social health inequalities. To do so, we examined the methods currently used to assess overall diet quality, in order to find the best method for analysis of the 1990 Québec Nutrition Survey data. This work was done to develop a common tool for eventual comparison of the Canadian nutrition surveys (all Canadian provinces will soon have conducted a nutrition survey on a representative sample of their respective population) and for comparison with surveys from other countries, mainly the USA.

\section{Materials and methods}

\section{Methods of assessing overall diet quality}

Though it is relatively easy to assess diet quality in terms of consumption of particular food items, developing a single indicator for the measurement of overall diet quality is a more complex task. It implies evaluating the combination of different nutrients issued from a large variety of foods. Consequently, it has always been difficult to evaluate the real impact of nutrition education on population health.

To make progress in this direction, various methods of assessing overall diet quality in broad population groups have been developed over the past few years. Some authors have adapted statistical methods such as factor and cluster analyses to process data from surveys of individual eating habits (food diaries, 24-hour recall, etc.). The method of factor analysis ${ }^{8-10}$ examines food groups to determine the main components of the diet ${ }^{10}$. This method identifies food consumption models as applied to individuals but does not allow direct comparison with dietary recommendations. Moreover, each individual may belong to different food groups, making it difficult to interpret the data in terms of specific health outcome ${ }^{9,11}$. Cluster analysis $^{12,13}$ also groups individuals in terms of similarities in food consumption patterns, but based on mutually exclusive categories ${ }^{11}$. The findings from different studies show how useful this method can be in defining dietary models that characterize different subgroups of a population. It is also helpful to identify various dietary models capable of predicting certain chronic diseases ${ }^{11-16}$. However, as this method is very sensitive to the type of data collected, it does not readily lend itself to comparisons between surveys based on differing data-collection methods ${ }^{11}$.

To study the relationship between eating habits and nutrition recommendations, other types of analyses examine either adequate intake of nutrients or models of food patterns. Analysis of nutritional intake may take the form of a nutrient adequacy ratio (NAR), of a mean adequacy ratio (MAR) or of an index of nutritional quality (INQ) ${ }^{17,18}$. These nutrient-based methods can be used to characterize food models for various groups of individuals, but not to draw conclusions regarding food consumption as proposed to the population in the dietary guidelines of different countries. Food pattern analysis, for its part, takes either the core food approach identifying the foods most frequently consumed by groups of individuals ${ }^{19,20}$, or the food group approach reviewing the quality and diversity of the food eaten ${ }^{21,22}$.

These different methods have been the wellspring of modes of monitoring how the nutrients and foods included in broad nutrition surveys evolve in relation to nutrition recommendations. These indicators of quality of the total diet seem to be more adequate for analyses concerned with population health, because they take into account the complexity of the diet ${ }^{23}$.

\section{Databases and indicators used}

We were interested in finding the best method to analyse the Québec Nutrition Survey data. We examined three of the methods currently used to assess overall diet quality: the diet quality index (DQI) developed by Patterson et $a l .{ }^{24}$, the healthy eating index (HEA) developed by Kennedy et $a l .{ }^{25}$ and the healthy diet indicator (HDI) used by Huijbregts et al. ${ }^{26}$. Other methods of global diet assessment such as the modified $\mathrm{DQI}^{27}$, the Mediterranean diet score $^{28}$ or the prudent dietary score ${ }^{29}$ were not examined, either because they are derivatives of the methods we chose or because they are not readily adaptable to the Québec Nutrition Survey data.

As outlined below, we first adjusted the DQI, HEA and HDI to the 1990 Canadian nutrition recommendations ${ }^{5}$. We then analysed the data from the 1990 Québec Nutrition Survey. We used each of the methods to compare their effectiveness and to choose the better one for the study of the Québec nutrition data. The Québec Nutrition Survey was conducted by Santé Québec in $1990^{30}$. The survey's sample - 2103 individuals of both sexes between the ages of 18 and 74 years - was representative of the population of Québec for the age groups included. All subjects responded to a 24-hour recall. We did not include the consumption of vitamin and mineral supplements in our analyses $(n=605)$, because Canadian recommendations are focusing on the satisfaction of nutritional needs through food, except under certain specific conditions ${ }^{5}$.

\section{Adjusting the indicators to the Canadian nutrition recommendations}

\section{Patterson's diet quality index}

Patterson et al. ${ }^{24}$ developed a diet quality indicator to assess the relationship between eating habits and the risk 
of food-linked chronic diseases. This indicator has eight components. It was estimated and validated based on a 3-day period consisting of 24-hour recalls and a 2-day food diary collected as part of the 1987/88 Nationwide Food Consumption Survey of 5845 adults aged 21 and over. We adapted the components of this indicator which is based on American dietary recommendations, to the Canadian model (Table 1). The indicator attributes a score of 0,1 or 2 to each component. The individual who totally meets the recommendation receives a score of 0 ; a score of 1 is attributed when the recommendation is almost met; and a score of 2 when the individual does not meet the recommendation. The scores are then added, a total of 0 indicating an excellent diet.

\section{Kennedy's bealthy eating index}

Kennedy et al. ${ }^{25}$ proposed a summed measurement of diet quality which can either be used to relate changes in eating habits or serve as a health promotion tool. The indicator was constructed based on a 2-day food diary and a 24-hour recall approach drawn from the 1989/90 Continuing Survey of Food Intake by Individuals. This survey included 7500 individuals aged 2 years and over. The indicator includes 10 components, worth up to 10 points each. The individual receives no points if he or she fails to meet the criterion; 10 points if the criterion is met perfectly; and a proportional score if behaviour falls between the two extremes. The scores are then added for a maximum of 100 points, which would correspond to a perfect diet. In order to adapt the criteria to the Canadian recommendations (Table 2 ), we grouped the fruits and vegetables together. A maximum of 20 points was attributed to this group in keeping with the Kennedy model. The only problematical concept was the one related to variety. The authors propose a minimum of eight foods per 24-hour recall as a variety criterion. We tested this criterion by defining two methods for calculating variety the first based on 20 general food groups and the other on the 148 food groups defined by the Canadian Chart of Nutritional Elements. In addition to being difficult to standardize, neither of these two methods of calculation improved the indicator. We thus omitted both methods in favour of a more uniform method where two points were attributed each time an individual consumed at least one portion out of each of the food groups.

\section{Huijbregts' bealthy diet indicator}

The last indicator we examined was developed by Huijbregts et al. ${ }^{26}$ based on the dietary recommendations of the World Health Organization (WHO). It draws its data

Table 1 Diet quality index based on Patterson's diet quality index (DQI), adjusted to Canadian recommendations

\begin{tabular}{|c|c|c|c|}
\hline Recommendation & $\begin{array}{l}\text { Patterson } \\
\text { score }\end{array}$ & Criteria & Adjustment to Canadian food guide variables \\
\hline $\begin{array}{l}\text { Reduce total fat intake to } \leqslant 30 \% \\
\text { of energy }\end{array}$ & $\begin{array}{l}0 \\
1 \\
2\end{array}$ & $\begin{aligned} \leqslant & 30 \% \\
& 30-40 \% \\
> & 40 \%\end{aligned}$ & Total fat \\
\hline $\begin{array}{l}\text { Reduce saturated fatty acids intake to } \\
<10 \% \text { of energy }\end{array}$ & $\begin{array}{l}0 \\
1 \\
2\end{array}$ & $\begin{aligned} \leqslant & 10 \% \\
& 10-13 \% \\
> & 13 \%\end{aligned}$ & Total saturated fatty acid \\
\hline Reduce cholesterol intake to $<300 \mathrm{mg}$ daily & $\begin{array}{l}0 \\
1 \\
2\end{array}$ & $\begin{aligned} \leqslant & 300 \mathrm{mg} \\
& 300-400 \mathrm{mg} \\
> & 400 \mathrm{mg}\end{aligned}$ & Total cholesterol \\
\hline $\begin{array}{l}\text { Eat five or more servings daily of a } \\
\text { combination of vegetables and fruits }\end{array}$ & $\begin{array}{l}0 \\
1 \\
2\end{array}$ & $\begin{aligned} \geqslant & 5 \text { portions } \\
& 3-4 \text { portions } \\
& 0-2 \text { portions }\end{aligned}$ & Food groups = fruits, vegetables, fruit juice \\
\hline $\begin{array}{l}\text { Increase intake of starches and other } \\
\text { complex carbohydrates by eating six } \\
\text { or more servings daily of breads, } \\
\text { cereals and legumes }\end{array}$ & $\begin{array}{l}0 \\
1 \\
2\end{array}$ & $\begin{aligned} \geqslant & 6 \text { portions } \\
& 4-5 \text { portions } \\
& 0-3 \text { portions }\end{aligned}$ & $\begin{array}{l}\text { Food groups = breads, cereals, rice, } \\
\text { legumes, nuts, grains }\end{array}$ \\
\hline $\begin{array}{l}\text { Maintain protein intake at moderate } \\
\text { levels (levels lower than twice the RDA) }\end{array}$ & $\begin{array}{l}0 \\
1 \\
2\end{array}$ & $\begin{aligned} \leqslant & 100 \% \text { RDA } \\
& 100-150 \% \text { RDA } \\
> & 150 \% \text { RDA }\end{aligned}$ & Based on RNI \\
\hline $\begin{array}{l}\text { Limit daily intake of sodium to } \leqslant 6 \mathrm{~g} \\
(2400 \mathrm{mg})\end{array}$ & $\begin{array}{l}0 \\
1 \\
2\end{array}$ & $\begin{aligned} \leqslant & 2400 \mathrm{mg} \\
& 2400-3400 \mathrm{mg} \\
> & 3400 \mathrm{mg}\end{aligned}$ & Sodium \\
\hline $\begin{array}{l}\text { Maintain adequate calcium intake } \\
\text { (approximately RDA levels) }\end{array}$ & $\begin{array}{l}0 \\
1 \\
2\end{array}$ & $\begin{aligned} \geqslant & \text { RDA } \\
& \text { 2/3 RDA } \\
< & 2 / 3 \text { RDA }\end{aligned}$ & Based on RNI \\
\hline $\begin{array}{l}\text { Scores }(0,1,2) \text { are summed across the } \\
\text { eight recommendations to develop a } \\
\text { diet quality score for an individual }\end{array}$ & $\begin{array}{l}\text { Range: } 0-16 \\
\text { Best score is } 0 \\
\text { Worst score is } 16\end{array}$ & & \\
\hline
\end{tabular}

RDA, recommended daily allowance; RNI, recommended nutritional intake. 
Table 2 Diet quality index based on Kennedy's healthy eating index (HEA), adjusted to Canadian recommendations

\begin{tabular}{|c|c|c|c|}
\hline Component & Modified Kennedy maximum score* & Score 0 & Variables \\
\hline 1. Grains & $\begin{array}{l}1600 \text { kcal: } 5 \text { servings } \\
2200 \text { kcal: } 9 \text { servings } \\
2800 \text { kcal: } 12 \text { servings }\end{array}$ & 0 servings & $\begin{array}{l}\text { Food groups = breads, cereals, rice, } \\
\text { pastries }\end{array}$ \\
\hline $2 / 3$. Fruits and vegetables & $\begin{array}{l}1600 \text { kcal: } 5 \text { servings } \\
2200 \text { kcal: } 7 \text { servings } \\
2800 \text { kcal: } 10 \text { servings }\end{array}$ & 0 servings & Food groups = fruits, fruit juice, vegetables \\
\hline 4. Milk & $\begin{array}{l}1600 \text { kcal: } 2 \text { servings } \\
2200 \text { kcal: } 2 \text { servings } \\
2800 \text { kcal: } 2 \text { servings }\end{array}$ & 0 servings & $\begin{array}{l}\text { Food groups = milk, yoghurt, cream, } \\
\text { ice-cream, cheese }\end{array}$ \\
\hline 5. Meat & $\begin{array}{l}1600 \text { kcal: } 2 \text { servings } \\
2200 \text { kcal: } 2.5 \text { servings } \\
2800 \text { kcal: } 3 \text { servings }\end{array}$ & 0 servings & $\begin{array}{l}\text { Food groups=meat, poultry, fish, egg, } \\
\text { legumes, nuts }\end{array}$ \\
\hline 6. Total fat & $\leqslant 30 \%$ energy from fat & $\begin{array}{l}\geqslant 45 \% \text { energy from } \\
\text { fat }\end{array}$ & Total fat \\
\hline 7. Total saturated fatty acids & $<10 \%$ energy from saturated fat & $\begin{array}{l}\geqslant 15 \% \text { energy from } \\
\text { saturated fat }\end{array}$ & Total saturated fatty acid \\
\hline 8. Cholesterol & $<300 \mathrm{mg}$ & $\geqslant 450 \mathrm{mg}$ & Total cholesterol \\
\hline 9. Sodium & $<2400 \mathrm{mg}$ & $\geqslant 4800 \mathrm{mg}$ & Sodium \\
\hline 10. Variety & At least 1 serving of each food group & $\begin{array}{l}\text { Not all food groups } \\
\text { consumed }\end{array}$ & Number of servings in each food group \\
\hline $\begin{array}{l}\text { Scores are summed across } \\
\text { the } 10 \text { components to give } \\
\text { the indicator }\end{array}$ & $\begin{array}{l}\text { Range: } 0-100 \\
\text { Best score is } 100 \\
\text { Worst score is } 0\end{array}$ & & \\
\hline
\end{tabular}

* The maximum score for each component is 10; components 2 and 3 have been combined so the maximum score is 20.

from dietary histories from the 1969/70 Seven Countries Study. We adjusted this indicator, composed of nine elements, to the Canadian recommendations (Table 3). Owing to gaps in data in our tables of nutrients, we replaced the item 'complex carbohydrates' with 'total carbohydrates', whereas the item 'monosaccharides and disaccharides' was omitted. This indicator attributes one point if the individual meets the criteria of the component and no

Table 3 Diet quality index based on Huijbregts' healthy diet indicator (HDI), adjusted to Canadian recommendations

\begin{tabular}{|c|c|c|c|}
\hline \multirow[b]{2}{*}{ Nutrient or food groups (daily intake) } & \multicolumn{2}{|c|}{ Huijbregts' } & \multirow[b]{2}{*}{ Adjustment to Canadian recommendations } \\
\hline & Score & Criteria & \\
\hline Saturated fatty acids ( $\%$ of energy intake $)^{\star}$ & $\begin{array}{l}0 \\
1\end{array}$ & $\begin{aligned}> & 10 \% \\
& 0-10 \%\end{aligned}$ & Total saturated fatty acids \\
\hline Polyunsaturated fatty acids (\% of energy intake)* & $\begin{array}{l}0 \\
1\end{array}$ & $\begin{array}{c}<3 \text { or }>7 \\
3-7\end{array}$ & Total polyunsaturated fatty acids \\
\hline Protein ( $\%$ of energy intake) ${ }^{*}$ & $\begin{array}{l}0 \\
1\end{array}$ & $\begin{array}{c}<10 \text { or }>15 \\
10-15\end{array}$ & Protein \\
\hline Complex carbohydrates ( $\%$ of energy intake)* & $\begin{array}{l}0 \\
1\end{array}$ & $\begin{array}{c}<50 \text { or }>70 \\
50-70\end{array}$ & Total carbohydrates \\
\hline Dietary fibre $(g)$ & $\begin{array}{l}0 \\
1\end{array}$ & $\begin{array}{l}<27 \text { or }>40 \\
27-40\end{array}$ & Total dietary fibre \\
\hline Fruits and vegetables $(\mathrm{g})$ & $\begin{array}{l}0 \\
1\end{array}$ & $\begin{array}{l}<400 \\
\geqslant 400\end{array}$ & Food groups $=$ fruits, vegetables, fruit juice \\
\hline Pulses, nuts and seeds (g) & $\begin{array}{l}0 \\
1\end{array}$ & $\begin{array}{l}<30 \\
\geqslant 30\end{array}$ & Food groups = legumes, nuts, seeds \\
\hline Monosaccharides and disaccharides (\% of energy Intake)* & $\begin{array}{l}0 \\
1\end{array}$ & $\begin{aligned}> & 10 \\
& 0-10\end{aligned}$ & Removed \\
\hline Cholesterol (mg) & $\begin{array}{l}0 \\
1\end{array}$ & $\begin{aligned}> & 300 \\
& 0-300\end{aligned}$ & Total cholesterol \\
\hline $\begin{array}{l}\text { Scores }(0,1) \text { are summed across the nine } \\
\text { recommendations to develop a diet } \\
\text { quality score for an individual }\end{array}$ & $\begin{array}{l}\text { Range: } 0-9 \\
\text { Best score is } 9 \\
\text { Worst score is } 0\end{array}$ & & $\begin{array}{l}\text { Scores }(0,1) \text { are summed across the eight } \\
\text { recommendations to develop a diet quality } \\
\text { score for an individual } \\
\text { Range: } 0-8 \text {; best }=8 \text {; worst }=0\end{array}$ \\
\hline
\end{tabular}

*Energy intake is calculated without alcohol. 
points in the opposite case. The final score is obtained by adding the components, a total of eight points indicating an excellent diet.

\section{Results}

\section{Comparisons between the three methods}

The statistical description of each of the components of the Québec Nutrition Survey for each of the indicators studied is presented in Table 4. The Patterson indicator has the score for the best diet at zero and this indicator forces us to think the reverse of what seems natural. The interpretation of this indicator is also difficult due to its expression as an ordinal variable with a total of 16 points. For the purpose of comparison and further analyses, we therefore reversed the score and changed it into percentages. Huijbregt's indicator (HDI) is also expressed as an ordinal variable, which makes it more difficult to interpret in terms of percentages and thus harder to use in certain types of statistical analyses calling for a continuous variable. We also changed it into percentages. Each score has then been calculated on a positive scale from 0 to 100 . These results are comparable to those obtained by the authors of the different indicators.

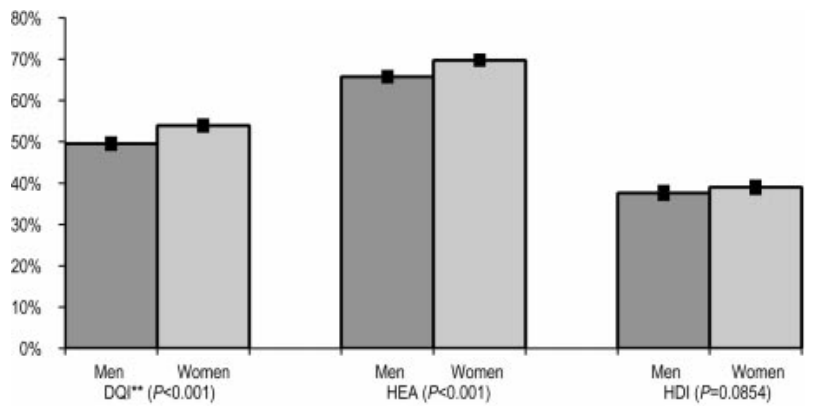

Fig. 1 Mean of the quality index for the three methods, by sex (DQIs and HDIs are transformed on a percentage scale and DQIs have been reversed)

The distribution of each of the indicators presented follows a normal curve. Only the DQI and the HEA show significant differences with regard to sex, indicating that women score better than men do (Fig. 1).

Having measured the correlation between the indicators studied, we found that the DQI was the indicator which correlated best with the other two, but the strongest correlation was between HEA and DQI $\left(r^{2}\right.$ (DQI,HEA) $=-0.757$, $\left.r_{(\mathrm{DQI}, \mathrm{HDI})}^{2}=-0.681\right)$. This is presumably due to the similarity of certain elements measured by these two indicators.

Table 4 Results of the three diet quality indices for each component, for the Québec Nutrition Survey data

\begin{tabular}{|c|c|c|c|c|c|}
\hline Components* & Mean & SD & Median & Minimum & Maximum \\
\hline \multicolumn{6}{|l|}{ DQI } \\
\hline Total fat & $33.5 \%$ & $8.7 \%$ & $33.7 \%$ & $0 \%$ & $68.9 \%$ \\
\hline Total saturated fatty acids & $12.4 \%$ & $4.3 \%$ & $12.1 \%$ & $0 \%$ & $36.5 \%$ \\
\hline Total cholesterol & $309.6 \mathrm{mg}$ & $230.0 \mathrm{mg}$ & $253.9 \mathrm{mg}$ & $0 \mathrm{mg}$ & $2854 \mathrm{mg}$ \\
\hline Vegetables, fruits & 4.9 servings & 3.3 servings & 4.3 servings & 0 servings & 24.9 servings \\
\hline Breads, cereals, legumes & 5.1 servings & 3.6 servings & 4.2 servings & 0 servings & 30.6 servings \\
\hline Protein (\% of RNI) & $151.9 \%$ & $75.1 \%$ & $140.12 \%$ & $0 \%$ & $718.0 \%$ \\
\hline Sodium & $3167 \mathrm{mg}$ & $1729 \mathrm{mg}$ & $2861 \mathrm{mg}$ & $20 \mathrm{mg}$ & $15752 \mathrm{mg}$ \\
\hline Calcium ( $\%$ of RNI) & $107.1 \%$ & $65.3 \%$ & $94.4 \%$ & $0 \%$ & $564.4 \%$ \\
\hline Score & 51.8 & 16.6 & 50.0 & 6.3 & 93.8 \\
\hline \multicolumn{6}{|l|}{ HEA } \\
\hline Grains & 6.6 servings & 4.3 servings & 5.6 servings & 0 servings & 36.3 servings \\
\hline Vegetables, fruits & 4.9 servings & 3.3 servings & 4.3 servings & 0 servings & 24.9 servings \\
\hline Milk & 1.7 servings & 1.5 servings & 1.4 servings & 0 servings & 13.3 servings \\
\hline Meat & 3.1 servings & 2.3 servings & 2.5 servings & 0 servings & 21.5 servings \\
\hline Total fat & $33.5 \%$ & $8.7 \%$ & $33.7 \%$ & $0 \%$ & $68.9 \%$ \\
\hline Total saturated fatty acids & $12.4 \%$ & $4.3 \%$ & $12.1 \%$ & $0 \%$ & $36.5 \%$ \\
\hline Total cholesterol & $309.6 \mathrm{mg}$ & $230.0 \mathrm{mg}$ & $253.9 \mathrm{mg}$ & $0 \mathrm{mg}$ & $2854 \mathrm{mg}$ \\
\hline Sodium & $3167 \mathrm{mg}$ & $1729 \mathrm{mg}$ & $2861 \mathrm{mg}$ & $20 \mathrm{mg}$ & $15752 \mathrm{mg}$ \\
\hline Variety & 7.6 & 1.9 & 8 & 0 & 10.0 \\
\hline Score & 68.1 & 14.2 & 68.5 & 28.1 & 100.0 \\
\hline \multicolumn{6}{|l|}{ HDI } \\
\hline Total saturated fatty acids & $12.7 \%$ & $4.4 \%$ & $12.4 \%$ & $0 \%$ & $36.5 \%$ \\
\hline Total polyunsaturated fatty acids & $5.4 \%$ & $2.6 \%$ & $4.9 \%$ & $0 \%$ & $26.2 \%$ \\
\hline Protein & $16.8 \%$ & $5.1 \%$ & $16.1 \%$ & $0 \%$ & $48.7 \%$ \\
\hline Total carbohydrates & $48.9 \%$ & $10.0 \%$ & $48.9 \%$ & $7.6 \%$ & $100.0 \%$ \\
\hline Total dietary fibre & $16.0 \mathrm{~g}$ & $8.9 \mathrm{~g}$ & $14.4 \mathrm{~g}$ & $0 \mathrm{~g}$ & $88.5 \mathrm{~g}$ \\
\hline Vegetables, fruits & $507.9 \mathrm{~g}$ & $338.9 \mathrm{~g}$ & $448.8 \mathrm{~g}$ & $0 \mathrm{~g}$ & $2508.9 \mathrm{~g}$ \\
\hline Pulses, nuts, seeds & $11.5 \mathrm{~g}$ & $32.6 \mathrm{~g}$ & $0 \mathrm{~g}$ & $0 \mathrm{~g}$ & $506.0 \mathrm{~g}$ \\
\hline Total cholesterol & $309.6 \mathrm{mg}$ & $230.0 \mathrm{mg}$ & $253.9 \mathrm{mg}$ & $0 \mathrm{mg}$ & $2854.0 \mathrm{mg}$ \\
\hline Score & 38.6 & 19.2 & 37.5 & 0.0 & 100.0 \\
\hline
\end{tabular}

*DQIs and HDIs are transformed on a percentage scale; DQIs have been reversed. 
Table 5 Average of indicators for dieters, vegetarians, supplement users and self-perception of healthy eating habits

\begin{tabular}{|c|c|c|c|c|}
\hline & $n^{\star}$ & $\begin{array}{c}\text { DQI†§ } \\
\left(n^{*}=2103\right)\end{array}$ & $\begin{array}{c}\text { HEA } \\
\left(n^{*}=2103\right)\end{array}$ & $\begin{array}{c}\text { HDI† } \\
\left(n^{*}=2103\right)\end{array}$ \\
\hline \multicolumn{5}{|l|}{ Diet } \\
\hline Yes & 236 & $56.9(15.7)$ & $72.6(13.7)$ & $41.4(19.2)$ \\
\hline No & 1867 & $51.1(16.6)$ & $67.5(14.2)$ & $38.2(19.2)$ \\
\hline \multicolumn{5}{|l|}{ Vegetarian } \\
\hline Yes & 14 & $69.9(16.4)$ & $77.5(11.1)$ & $58.1(18.1)$ \\
\hline No & 2089 & $51.7(16.5)$ & $68.0(14.2)$ & $38.5(19.2)$ \\
\hline \multicolumn{5}{|l|}{ Supplements } \\
\hline Yes & 605 & $53.9(16.4)$ & $71.2(13.9)$ & 40.7 (19.3) \\
\hline No & 1498 & $50.9(16.6)$ & $66.7(14.1)$ & $37.7(19.1)$ \\
\hline \multicolumn{5}{|c|}{ Self-perception of healthy eating habits } \\
\hline Bad & 99 & 49.9 (19.9) & $61.6(16.1)$ & $34.7(22.1)$ \\
\hline Average & 512 & 49.9 (15.2) & 65.4 (13.7) & 36.8 (17.9) \\
\hline Good & 985 & $51.1(16.5)$ & $67.7(14.0)$ & 37.9 (19.0) \\
\hline Very good & 407 & $55.1(17.0)$ & 72.3 (13.9) & 41.5 (19.6) \\
\hline Excellent & 100 & $57.1(16.1)$ & 73.4 (12.2) & $45.7(20.0)$ \\
\hline
\end{tabular}

\section{Evaluation of some determinants of diet quality}

We verified how the indicators would react to factors such as dieting, being vegetarian or taking vitamin and mineral supplements, which are generally linked to quality of the diet. The results presented in Table 5 show significant differences for each of the indicators - all following the expected trend. As a matter of fact, dieters, vegetarians and those taking supplements scored better for each of the indicators studied $(P<0.0001)$. The distribution of indicators, established according to self-perceived eating habits, is also presented in Table 5.

\section{Total calories and alcobol consumption}

In the preceding tables and figure, calories from alcohol consumption were included in the total calories. However, we also wanted to assess the impact of exclusion of alcohol consumption on the diet quality indicators studied. This calculation was done only for the components of each of the indicators expressed as a percentage of calories consumed. Excluding the calories from alcohol resulted in a statistically significant $(P<0.001)$ drop in the score of each of the three indicators studied for the population. This drop is due to the fact that lipids (total fat, saturated and polyunsaturated fatty acids, cholesterol) contributed more to the index than other macronutrients.

\section{Estimation of the quality of the diet}

We then compared each of the indicators using the MAR ${ }^{21}$. This measurement averages the proportion of dietary recommendations met by an individual for each nutrient. This proportion is cut off at one to avoid overestimation of a nutrient which might act as a mathematical mask for the deficiency of some other nutrients. This measurement is often referred to as the food 'deficiency' indicator ${ }^{17}$. Given the non-normal MAR distribution, a Spearman correlation was used to compare the three DQI measurements with the MAR (Table 6).

When the Kennedy (HEA) method was used to calculate the indicator, we obtained a correlation coefficient distinctly higher than for the other two methods. Moreover, this

Table 6 Correlation between DQI, HEA and HDI and the mean adequacy ratio (MAR), and the self-perception of healthy eating habits

\begin{tabular}{lccc}
\hline & $\begin{array}{c}\text { DQI } \S \\
\left(n^{*}=2103\right)\end{array}$ & $\begin{array}{c}\text { HEA } \\
\left(n^{*}=2103\right)\end{array}$ & $\begin{array}{c}\text { HDI† } \\
\left(n^{*}=2103\right)\end{array}$ \\
\hline MAR (without added vitamins) & & & \\
$\quad$ Men & $-0.008(P=0.787)$ & $0.197(P<0.001)$ & $0.061(P=0.051)$ \\
$\quad$ Women & $0.031(P=0.307)$ & $0.391(P<0.001)$ & $0.101(P<0.001)$ \\
$\quad$ Total & $0.001(P=0.960)$ & $0.287(P<0.001)$ & $0.079(P<0.001)$ \\
Self-perception of healthy eating habits & & & \\
$\quad$ Men & $0.096(P=0.002)$ & $0.176(P<0.001)$ & $0.094(P=0.003)$ \\
$\quad$ Women & $0.126(P<0.001)$ & $0.224(P<0.001)$ & $0.121(P<0.001)$ \\
$\quad$ Total & $0.117(P<0.001)$ & $0.206(P<0.001)$ & $0.109(P<0.001)$ \\
\hline
\end{tabular}

*Unweighted.

†DQIs and HDIs are transformed on a percentage scale.

$\S$ DQIs have been reversed. 
indicator was the only one to show a gradation in the percentage of individuals reaching $75 \%$ of the dietary recommendations per nutrient. Still searching for the indicator best suited to analysis of the data from the Québec Nutrition Survey, we compared each of the indicators with respondents' self-perception of their eating habits (Table 6). Once again, the indicator based on Kennedy's method showed the best correlation coefficient.

\section{Discussion}

\section{Choice of an indicator for our analyses}

The indicator based on the method designed by Patterson et al. (DQI) and adjusted to the Canadian recommendations gave some information on diet quality. It did not, however, show a very strong correlation with the MARs. Adding all the food groups from the Patterson indicator made the Kennedy indicator (HEA) a more accurate instrument for measuring diet quality in terms of correlation coefficients. The combination of food groups and nutrients found in the Kennedy indicator is in line with the theoretical concept that an instrument for measuring overall diet quality should combine nutrient recommendations with dietary guidelines. This last indicator is also easier to interpret, the results being expressed directly in percentages and the maximum score being 100. Offering a continuous variable, the Kennedy indicator allows the use of a greater variety of statistical analyses. Therefore, the indicator developed by Kennedy and colleagues seems to be the best suited to our analyses and to their comparison with findings from the USA.

Certain questions such as whether or not to include calories derived from alcohol still remain unanswered. As Hulshof and collaborators ${ }^{31}$ remind us, very little is known regarding how calories from alcohol are metabolized, and dietary recommendations still do not specify whether they should or not be included in the total calorie count. Yet, including them in our analyses did raise the score for each of the indicators studied, presumably because calories derived from lipids then contribute less to the overall index. Regardless of whether or not to include alcohol in the total calories count, there is none the less increasing evidence that moderate alcohol consumption (15-30 $\mathrm{ml}$ of ethanol day ${ }^{-1}$ ) may protect against coronary heart disease both by increasing high density lipid (HDL)-cholesterol concentrations and by protecting low density lipids (LDLs) from oxidation (phenolic compounds of red wine) ${ }^{32}$. On the other hand, overconsumption of alcohol, in addition to having unfavourable metabolic consequences such as increasing plasma triglycerides and promoting weight gain, can also engender behavioural and social problems (alcoholism, reduced road safety, etc.). Consequently, one can wonder whether alcohol consumption should be incorporated into models developed to assess diet quality.

Another of the difficulties encountered relates to which foods should be included in each of the food groups. A clearer definition of variety would be useful. Despite these limitations, it will be of interest to repeat these analyses on the nutrition survey of other Canadian provinces, because dietary recommendations are the same across the country. It will thus be possible to evaluate intra- and interprovincial variations in diet quality and to conduct further analyses on nutrition as a determinant of population health.

\section{Overall measurement of diet quality and compliance to the recommendations}

Authors assessing the percentage of the population complying with criteria of a country's dietary recommendations usually obtain very weak scores ${ }^{4,33,34}$, and our findings in the Québec population are in keeping with these observations. The generally accepted idea about affluent societies offering such a wide variety of food items that everybody should easily satisfy their nutritional needs should therefore be revised. Though this holds true for nutrient deficiencies, it is another matter for chronic diseases calling for maximum rather than minimum recommendations. In this regard, nutrition indicators should be better adapted to individual needs, for example in terms of energy, to capture the determinants of excess body weight and obesity in a population.

Comparative analyses of health inequalities require the development of a standardized indicator capable of assessing the role of nutrition for population health. However, this nutrition indicator must be adjusted to the nutrition recommendations - which vary from country to country and to the different ways of collecting data in nutrition surveys. It appears that the 24-hour recall method currently used in surveys does allow for global assessment of diet quality ${ }^{25}$. Also, an indicator is only valid to the extent that it corresponds to the groups for which the dietary recommendations were developed. For certain groups of the population (the poor, the aged, some ethnic minorities), the chosen indicator may not prove valid. Similarly, it could be inadequate to assess the quality of the diet for one population, based on the recommendations developed for another, especially when their eating habits differ greatly. Recommendations will also vary over time. For example, the harmonization of the dietary recommendations in the USA and in Canada will require a process of continuous revision. This must imply corresponding adjustments in the components of the diet quality indicator.

It is also important to develop indicators to monitor the quality of the diet of children and adolescents, so as to measure the delay factor typical of chronic diseases and longevity in developed countries, especially because some indicators linked to population health show that conditions have been deteriorating over the past few years (increased obesity, more low birth weight babies, more children living in poverty, etc.). Nestle ${ }^{4}$ has even invoked a nutritional backlash in the USA, where concerns for health and healthy diets are losing ground to the benefit of 
eating patterns similar to those seen in the 1950s. Development of an indicator capable of monitoring overall diet quality is thus of great importance for future years. Because there is a gap between the establishment of dietary recommendations and the development of nutrition education tools, we may also surmise that individual behaviours will not be immediately affected by the recommendations established. Then, the indicator can also serve to measure the lag time in the impact of recommendations.

The population health model ${ }^{35}$ calls for a global vision for the analysis of the whole diet in terms of comprehensive health indicators, rather than in terms of risk factors linked to one specific chronic disease. With such comprehensive standard indicators, it would be possible to determine the role of nutrition in health inequalities and to obtain a clearer view of the role of social position in such inequalities. Social transformations such as the ageing of the population, the changing of family structures and the development of new types of food products with healthrelated claims ${ }^{36}$ also plead in favour of establishing a standard measurement capable of tracking the impact of these transformations on population health.

\section{Acknowledgements}

The authors would like to thank the Conseil Québécois de la Recherche Sociale (CQRS) for their grant supporting this research.

\section{References}

1 Lewis CJ, Crane NT, Moore BJ, Hubbard VS. Healthy people 2000. Report on the 1994 nutrition progress review. Nutr. Today 1994; 29(6): 6-13.

2 Federal-Provincial and Territorial Committee on the Health of the Population. Report on the Health of Canadians. Ottawa: Ministry of Supplies and Health Canada, 1996.

3 McKeown T. The Origins of Human Disease. Oxford: Basil Blackwell, 1988.

4 Nestle M. Dietary guidance for the 21st century: new approaches. J. Nutr. Educ. 1995; 27(5): 272-5.

5 Health and Welfare Canada. Recommendations on Nutrition, Report of the Scientific Review Committee. Ottawa: Supplies and Services Canada, 1990.

6 Monsen ER. New dietary reference intakes proposed to replace the recommended dietary allowances. J. Am. Diet. Assoc. 1996; 96(8): 754-5.

7 Food and Nutrition Board. How should the recommended dietary allowances be revised? A concept paper from the Food and Nutrition Board. Nutr. Rev. 1994; 52(6): 216-19.

8 Nicklas TA, Webber LS, Thompson B, Berenson GS. A multivariate model for assessing eating patterns and their relationship to cardiovascular risk factors: the Bogalusa Heart Study. Am. J. Clin. Nutr. 1989; 49: 1320-7.

9 Randall DE, Marshall JR, Brasure J, Graham S. Patterns in food use and compliance with NCI dietary guidelines. Nutr. Cancer 1991; 15: 141-58.

10 Barker ME, Thompson KA, McClean SI. Do type As eat differently? A comparison of men and women. Appetite 1996; 26: 277-86.

11 Wirfält AKE, Jeffery RW. Using cluster analysis to examine dietary patterns: nutrient intakes, gender, and weight status differ across food pattern clusters. J. Am. Diet. Assoc. 1997; 97: 272-9.

12 Akin JS, Guilkey DK, Popkin BM, Fanelli MT. Cluster analysis of food consumption patterns of older American states. J. Am. Diet. Assoc. 1986; 86(5): 616-25.

13 Hulshof KFAM, Wedel M, Löwik MRH, et al. Clustering of dietary variables and other lifestyle factors. J. Epidemiol. Community Health 1992; 46: 417-24.

14 Tucker KL, Dallal GE, Rush D. Dietary patterns of elderly Boston-area residents defined by cluster analysis. J. Am. Diet. Assoc. 1992; 92: 1487-91.

15 Farchi G, Fidanza F, Grossi P, et al. Relationship between eating patterns meeting recommendations and subsequent mortality in 20 years. Eur. J. Clin. Nutr. 1995; 49: 408-19.

16 Huijbregts PPCW, Feskens EJM, Kromhout D. Dietary patterns and cardiovascular risk factors in elderly men: the Zutphen Elderly Study. Int. J. Epidemiol. 1995; 24(2): 31320.

17 Murphy SP, Rose D, Hudes M, Viteri FE. Demographic and economic factors associated with dietary quality of life for adults in the 1987-88 Nationwide Food Consumption Survey. J. Am. Diet. Assoc. 1992; 92(11): 1352-7.

18 Windham CT, Wyse BW, Hurst RL, Hansen RG. Consistency of nutrient consumption in the United States. J. Am. Diet. Assoc. 1981; 78: 587-95.

19 Fanelli MT, Stevenhagen KJ. Characterizing consumption patterns by food frequency methods: core foods and variety of foods in diets of older Americans. J. Am. Diet. Assoc. 1985; 85(12): 1570-6.

20 Koehler KM, Harris MB, Davis SM. Core, secondary, and peripheral foods in the diets of Hispanic, Navajo, and Jemez Indian children. J. Am. Diet. Assoc. 1989; 89: 538-40.

21 Guthrie HA, Scheer JC. Validity of a dietary score for assessing nutrient adequacy. J. Am. Diet. Assoc. 1981; 78 $240-5$.

22 Kant AK, Schatzkin A, Block G, et al. Food group intake patterns and associated nutrient profiles of the US population. J. Am. Diet. Assoc. 1991; 91: 1532-7.

23 Kant AK. Indexes of overall diet quality: a review. J. Am. Diet. Assoc. 1997; 96: 785-91.

24 Patterson RE, Haines PS, Popkin BM. Diet quality index: capturing a multi-dimensional behavior. J. Am. Diet. Assoc 1994; 94(1): 57-64.

25 Kennedy ET, Ohls J, Carlson S, Fleming K. The healthy eating index: design and applications. J. Am. Diet. Assoc. 1995; 95: 1103-8.

26 Huijbregts PPCW, Fesken E, Räsänen L, et al. Dietary pattern and 20 year mortality in elderly men in Finland, Italy, and the Netherlands: longitudinal cohort study. BMJ 1997; 315(5): 13-17.

27 Drewnowski A, Henderson SA, Shore AB, et al. Diet quality and dietary diversity in France: implications for the French paradox. J. Am. Diet. Assoc. 1996; 96: 663-9.

28 Trichopoulou A, Kouris-Blazos A, Wahlqvist ML, et al. Diet and overall survival in elderly people. BMJ 1995; 311: 1457 60 .

29 Nube M, Kok FJ, Vandenbroucke JP, et al. Scoring of prudent dietary habits and its relation to 25 -year survival. J. Am. Diet. Assoc. 1987; 87(2): 171-5.

30 Santé Québec, Bertrand L. Les Québécoises et les Québécois mangent-ils mieux? Rapport de l'enquête québécoise sur la nutrition, 1990. Montreal: Ministry of Health and Social Services, Government of Quebec, 1990.

31 Hulshof KFAM, Wedel M, Löwik MRH, et al. Clustering of dietary variables and other lifestyle factors. J. Epidemiol. Community Health 1992; 46: 417-24.

32 Savolainen MJ, Kesäniemi YA. Effects of alcohol on lipoproteins in relation to coronary heart disease. Curr. Opin. Lipidol. 1995; 6(4): 243-50.

33 Smith AM, Baghurst KI. Public health implications of dietary 
differences between social status and occupational category groups. J. Epidemiol. Community Health 1992; 46: 409-16.

34 Pryer J, Brunner E, Elloitt P, et al. Who complied with COMA 1984 dietary fat recommendations among a nationally representative sample of British adults in 1986-1987 and what did they eat? Eur. J. Clin. Nutr. 1995; 49: 1-11.
35 Evans RG, Stoddart GL. Producing health, consuming health care. In: Evans RG, Barer ML, Marmor TR, eds. Why are Some People Healthy and Others Not. The Determinants of Health of Populations. New York: Aldine de Gruyter, 1994.

36 Dubois L. L'aliment, un futur miracle de la biotechnologie? Sociol. Soc. 1996; 28(2): 45-57. 